\title{
ЛІНГВОКОНЦЕПТОЛОГІЯ
}

УДК 811.161.2’373.612.2

В. Є. Бєлінська

\section{ІНДИВІДУАЛЬНО-МОВНА КОНЦЕПТОСФЕРА П. ПЕРЕБИЙНОСА}

У статті описано особливості ідіостилю украӥнського поета П. Перебийноса: пріоритетність ландшафтного опису, фольклорність, метафоричність, візуальність, інтимність. Досліджено ареальний і ментальний аспекти формування індивідуальної мовної картини світу поета. Визначено тематичні пріоритети його творчості, що репрезентовані концептуальними категоріями «село», «степ», «космос», «хата», «Україна».

Ключові слова: П. Перебийніс, поезія, метафорична конструкиія, кониелт, МКС, ландшабтний опис.

Bielinska V. Ye. Individual and Lingual P. Perebyinis's Conceptosphere. The study is relevant because P. Perebyinis's creativity reveals ethnic priorities within relevant themes and vocabulary, concepts and metaphorical constructions. The ethnic and individual vision of the world, represented in the language picture of the world (referred to as the $L P W$ ), constitutes the general conceptual sphere of Ukrainian poetry.

The aim of this article is to investigate the features of the individual style of the Ukrainian poet P. Perebyinis, taking into account the elements of his individual LPW implemented in metaphorical constructions, epithetical phrases and in general in descriptions of the native landscape.

The tasks of the article are to analyze verbalizers of concepts and synonymous sequences of tokens for their notation in the text and to interpret their metaphorical content.

The lingual features of P. Perebyinis's individual style are folklore, represented by separate traditional forms (this in particular appeal to the objects of nature as living interlocutors), song (through appropriate features of verse), mastery of creating metaphorical constructions, where the poet juxtaposes elements of space and earth, flora, fauna and water worlds, natural elements and anthropomorphic features.

The article describes the Ukrainian poet P. Perebyinis' idiostile - the priority of landscape description, folklore, metaphoricity, visuality, intimacy. The areal and mental aspects of the formation of the individual poet's linguistic picture of the world are investigated. Thematic priorities of his work are determined. The thematic priorities of his work, which are represented by the categories conceptual «village», «steppe», «space», «house», «Ukraine» are determined.

Key words: P. Perebyinis, poetry, metaphorical construction, concept, LPW, landscape description, visual. 


\section{Вступ}

На сучасному етапі розвитку України кожен національно орієнтований український митець виконує неабияку роль у вихованні молодого покоління, що виросло вже в XXI столітті в незалежній державі. Дослідження творчості такого літератора виявляє власне етнічні пріоритети в межах відповідних тем і лексикону, концептів і метафоричних конструкцій. Етнічне й індивідуальне бачення світу, репрезентоване в мовній картині світу (далі - МКС), становить загальну концептосферу української поезії. Саме тому таке дослідження $\epsilon$ актуальним.

Серед українських поетів, які творили в попередню епоху та в сучасну, відзначаємо П. Перебийноса, що, за словами дослідників, «успішно подолав усі бар'єри становлення, прийшов у літературу впевнено й назавжди з колом своїх тем і проблем, зі своїм оригінальним стилем і неповторним поетичним голосом», зі «сміливими спробами проникнути у глибокі шари живої і національної культури, відштовхуючись від життєвого досвіду свого покоління, поет не тільки майстер пера, а й пристрасний історик свого народу, виразник його дум і прагнень» (Сорока, 2005: 29). Тобто зазначено, що ідіостиль поета відзначається саме етнічним характером, і для його аналізу потрібно враховувати екстралінгвальні чинники - біографію поета, сучасний йому історичний контекст, культурні й етнічні особливості. Л. Лисиченко додає до цих вимог ще й «індивідуально-психічні чинники, традиції поетичного мовлення, ідейно-художню спрямованість автора, що відбиті в його мові, зокрема це його бачення довкілля» (Лисиченко, 2009: 52).

\section{Методи та методики дослідження}

Питання розмежування етнічної мовної картини світу (далі МКС) та авторського простору в цій сфері докладно досліджує Ю. Лотман, який трактує останній як «модель світу певного автора, виражену мовою його просторових уявлень» (Лотман, 1996: 252253). Цю модель В. Маслова також називає «суб'єктивним образом об'єктивного світу», вона створюється однією особою - представником певного етносу, проте той самий літературний текст, що є репрезентацією авторської поетичної картини світу, пов'язаний з етнічною 
МКС, що формуються «під впливом складних когнітивних структур національної ментальності» (Маслова, 2004: 42-43).

Попри дотримання наведених вище вимог, дослідження ідіостилю поета традиційно передбачає визначення й аналіз ключових слів - вербалізаторів концептів - і синонімічних послідовностей лексем на їх позначення в тексті (А. Кощова), а також інтерпретацію їх метафоричного змісту (Кощова, 2013: 125); вербальних компонентів кінематографічності поетичного опису - візуальних, аудіальних, смакових, тактильних, а також елементів колористичної парадигми, що Л. Талалай назвав прикладом «мислення віршем, а не з допомогою вірша» (Талалай, 2011: 389); авторських новотворів - окремих слів (епітетів, метафор), фразеологізмів, образів, які, за словами Ю. Ковалева, можуть висвітлити «творчі сили, означені панівним для кожної доби типом світосприймання» (Ковалів, 2012: 101); вербальних елементів поетичної гри (стилістичні фігури, оказіональні конструкції, ситуативні форми), яку С. Жигун зазначає як головну ознаку ідіостилю (Жигун, 2008: 8); фольклорних ознак у поезіях, що, за словами Я. Поліщука, важливі «з огляду на ідеальну кодифікацію в ньому традиційної культури, основ національної ментальності» (Поліщук, 2008: 48). Це можуть бути і формальні елементи (фольклорна структура чи окремі мовні форми й образи), і контентуальні, що віддзеркалюють менталітет відповідного етносу.

Використовуючи вищенаведені чинники, ставимо за мету в цій статті дослідити особливості ідіостилю українського поета П. Перебийноса, ураховуючи елементи його індивідуальної МКС, що реалізовані в метафоричних конструкціях, епітетних словосполученнях і загалом в описах рідного ландшафту.

В. Базилевський зазначив, що «Перебийносів рух у поезії - по висхідній. Він од природи чоловік серйозний... ця серйозність серйозність селянина, який знає, що ніщо йому задарма не дається, що до всього треба докласти труду й за все треба заплатити» (Базилевський, 2011: 564). Уже з дитинства поет нерозривно пов'язаний із природою. В автобіографії від 1997 року П. Перебийніс метафорично описує свій зв'язок з рідною землею: «приріс думками і серцем» до своєї землі, «відкрив непомітну, незнану на планеті» цю землю читачам (Рубан, 1997: 52). 


\section{Результати та дискусії}

У літературному світі П. Перебийніс відомий більшою мірою як багаторічний редактор журналу «Київ та газети «Літературна Україна», має звання заслуженого діяча мистецтв і журналіста України. Проте його поетичні досягнення також вагомі - лауреат Національної премії України ім. Тараса Шевченка та багатьох інших, автор двох десятків поетичних книжок, що охоплюють його творчість - від збірки «Червоний акорд» 1971 року до «Цивілізація дерев» 2011 року, від традиційних тем радянської поезії (історія рідного народу, минула війна, ядерна загроза) до перебудовчих (пошуки місця людини у світі, відкриття темних сторінок історії, засудження кар'єризму) і власне українських (екологія, пацифістика тощо). Поет прагне відвертої розмови із читачем, виявляючи «зростання зору душі» (Сорока, 2005: 26), уживаючи сповідальні й філософські категорії, підносячи доброту як головний концепт людського існування загалом і поетового зокрема.

Попри означені тематичні площини, П. Перебийніс надає пріоритет опису рідної природи з використанням відповідно маркованих апелятивів (це видно вже з назв поезій, напр.: «Цвіт бузини», «Медівники», «Сад матерії», «Ой співає соловейко!», «Міф предковічного лісу»). Зокрема, у поезї «Пора цвітіння тютюну» автор метафорично описує природний цикл розвитку цієї рослини - від виростання до висихання: «Та п'ють росу круті судини, // жене тютюн стебло своє // і все, що квітам не судилось, // крихкому листю віддає. // Теплом струмує днина літня, // і грає в листі нікотин. // I поступово, непомітно // всиха тютюн од гіркоти» (Перебийніс, 1976: 5) (виділені фітоелементи в складі метафоричних конструкцій зіставлено з антропоелементами через дієслівні форми п'ють, не судилось, жене, віддає). У другій строфі метафоричні конструкції «грає в тисті нікотин» та «всиха тютюн од гіркоти» поєднують ніби два контенти - формальний / фізичний (визрівання, усихання, згірклість) та змістовий / продуктивний (отримання товарного тютюну).

Про метафоричну майстерність П. Перебийноса В. Рубан зазначає, що той досяг творчої вершини в пейзажному описі з використанням невживаних раніше метафор, у чому виявляється його справжній професіоналізм (Рубан, 1997: 51). Так, поет часто зіставляє елементи рослинного та водного світів: «Глухо хлюпають імлою // зелен-хвилі 
листяні. // Може, справді наді мною // давнє море? // Я на дні...» (Перебийніс, 1976: 81) (поряд із виділеною метафорою, це зіставлення конкретизується іменниками море та на дні).

У межах метафоричних конструкцій і поряд з ними слід відзначити й епітети П. Перебийноса - і стерті, і авторські, що загалом формують візуальність опису. Наприклад, у поезії «Діти вчаться плавати» (Перебийніс, 2005: 33) ми виділили фрагмент «... Тільки на пісочку золотому // хвиля норовиста не страшна», де поєднується сполука зі стертим епітетом (пісочок золотий) та сполука з авторським (хвиля норовиста), що акцентує саме на останній, підвищуючи в такий спосіб безстрашність хлопчаків.

На межі 90-х років у поезії з'являються нові теми, які хвилюють i П. Перебийноса. Наприклад, тема голодомору надто актуальна не лише як поминальне історичне явище, а й як проблема духовного розділу українського суспільства на тих, хто вважає ці події усвідомленим геноцидом, і тих, хто вважає це стихійною подією, не пов'язаною зі ставленням верховної влади до українців. Автор у поезії «1946-й. Посуха» будує метафоричні конструкції на жовтому кольорі (можна провести аналогію із «Жовтим князем» В. Барки), який найкраще передає його особисте сприйняття спеки на пшеничному полі, що в тих умовах асоціюється з жахом: «Жовта спека. // Жовто в очах. // Вертаю зі степy. // Жах!...». Ніби бачиться прозоре літнє небо, де «на обрії хмарка», і ця хмарка дає сподівання на можливий дощ: «Мама ... молиться дощу» (Перебийніс, 1990: 57). Образ матері в такому контексті виявляє поетову чутливість i, відповідно, створює контраст між невмолимим негативом (тимчасові негаразди) і родинним позитивом (вічні чесноти).

У поета з'являються й трансцендентальні мотиви. Зокрема, у поезії «Божественний стандарт» автор описує ландшафтне розташування славетного монастиря, зіставляючи його із живою істотою (через виділені ознаки): «Над скелями задумався похмуро // святий Новоафонський монастир. // Вікониями з напруженим прижмуром // на море позира, мов на пустир» (Перебийніс, 1976: 79). Він, звичайно, відзначається ознаками вищості - формальними (над скелями; на море позира) та змістовими (святий).

Поетична мова П. Перебийноса відзначається й такою характерною для української поезії рисою, як пісенність. У поета вона 
безпосередньо пов'язана з фольклорністю. Наприклад, у фрагменті «Ой співає соловейко, // заливається! // Ой кує ж та зозуленька // за левадою!» (Перебийніс, 1976: 98) формами, властивими народній пісні, є виділені окличні конструкції, а також орнітоніми соловейко та зозуленька, що репрезентують українську фольклорну традицію.

3 фольклорністю також пов'язана така ознака ідіостилю поета, як казковий опис. Таких фрагментів у поезіях багато - як ситуативних (наприклад, метафорична конструкція «ялинка сухо чапає // примороженими лапами // через поле до села» (Перебийніс, 1990: 45) маніфестує ірреальну (казкову) ситуацію, що базується на зовнішньому зіставленні розлогої ялинки з певним звіром у контексті уявного іiі руху), так і конструктивних - у межах творів, спеціально присвячених казковій ситуації. Наприклад, у поезії з відповідною назвою «Казки Новоафонської печери» сполучаються метафоричні елементи казкового опису («удивнім сяйві», «скелі сургучеві риплять», «у синій загадковій глибині», «зловісно сяють ікла сталактитів», «регочуть хижі пащі кам'яні», «зеленим оком древнього изиклопа // внизу підземне озеро скипа») та трансцендентального («з небес печери», «крізь вічну ніч», «печерні хащі галактичні» і сам об'єкт опису - Новоабонська печера, що розташована в центрі православ’я) (Перебийніс, 1976: 77).

П. Перебийніс, як поет своєї епохи, починає використовувати окремі слова, що стали на той час активно вживаними. Зокрема, наприкінці 80-х спливло слово геноцид щодо історичних подій у Нагорному Карабаху, на Кіпрі, у Криму й, зрештою, в Україні (щодо голодомору). У митця ця лексема може набувати й трагікомічного відтінку: у поезії «Соняшниковий геноцид» (Перебийніс, 1990: 102) описано стосунки людей і соняшників у процесі збирання цієї рослини. Це виявляється у словосполученнях з ключовими негативними лексемами: «починається різня», «летять на землю неповинні голови», «стоячи вмирає сонячниковий народ», «захмелілі від зеленої крові ножі не знають пощади». При цьому ознака моторочний (сонящниковий геноцид) набуває візуальності: автор ніби малює панораму після тієї «різні»: «у веселому небі // прямо і незрушно // стирчать // безголові зелені штурпаки», де наявна семантична антитеза - «веселе небо» / «стирчать безголові штурпаки». В окремих ознаках «соняшникового народу» автор виявляє конкретні людські риси: це відповідні означення у сполуках гордовиті соняхи, непокірний сонячниковий 
народ і теза коріння не вмирає, що наявні в поетових характеристиках інших природних об'єктів - дерев, Дніпра, зеленого росточка під асфальтом. Загалом це ознака невмирущості етносу як частки природи та Всесвіту.

Активне вживання слова екологія було зумовлене спочатку потребою захисту природи, а пізніше - й духовної сфери людини. У поезії «Екологічний етюд» сливовий сад від роботи сусідньої техніки із зеленого став бурим, між деревами постали наїжачені нетрі залізні, димарі поміж стовбурів. Однак ще «грона слив мерехтять загадково, мов осінні зірки голубі», хоча й уже «димлять, догоряють», і фінальна фраза автора «та не дуже чомусь довіряю // прохолодному и,ьому димку» сприймається як недовіра до сучасної цивілізації та ії сумнівних здобутків (Перебийніс, 1990: 103). Деякі ознаки семантично репрезентують нещадність сучасного технологічного світу через зіставлення духовних і технологічних елементів: «Атоми крові. - Атоми стронцію», «Плями на сонці - Плями на совісті». Однак життя на Землі продовжується («колиска ще гойдається»), і у Всесвіті «Земля ще крутиться», а поетові за все це болить («я - в кожній грудочціџ) (Перебийніс, 1990: 104). Тобто в цьому контексті зіставляються і мінорні, і мажорні ознаки.

На сучасному етапі творчого шляху П. Перебийніс виявляє і нові форми (наприклад, більшою мірою поезії подаються без формальної назви), і нові контенти (наприклад, антиколоніальні), що свідчить про його зростання як особистості. Зокрема, у поезії «Ой шукала раю...» (2011 рік) розповідається про журавлину зграю, яка шукала кращого життя, але «зустріла двоголового орла», і тому в нещасної зграї вже «ні двора, ні кола...», бо «не буває раю // під крилом орла» (Перебийніс, 2011: 454). Виділене словосполучення позначає владу Російської імперії (двоголовий орел - iї герб, що вже самою своєю сутністю вказує на імперський характер тієї держави), а журавлина зграя - то українці.

В останніх поезіях П. Перебийніс оглядається на своє минуле, підсумовує життя. За словами М. Слабошпицького, у поета «увиразнюється мотив підсумків. <...> Це підсумки зрілості...» (Слабошпицький, 2011: 571). Саме тому активно провадиться тематика захисту світу, протистояння людини та природи, урбаністики та сільської культури. Наприклад, характеристика міста має обов'язковий елемент - бетон (або асфальт), що в цьому контексті виявляє сему 
негативного тиску: «Чую крізв бетони // гомони столиць» (Перебийніс, 2011: 442) (виділена ознака ніби створює певну завісу, перепону для сприйняття людини - ліричного героя). Ця характеристика доповнюється негативно конотованими урбаністичними ознаками в словосполученнях «нуртує місто», «у зінииях вікон», «на велетах багатоповерхових». Як здобутки цивілізації визначаємо інші ознаки: «блакитно фосфорують кінескопи», «пороша вимережує антени», «нуртує місто океаном вікон» (Перебийніс, 2005: 276).

Поезії, присвячені сучасним викликам людства, характеризуються загалом песимістичністю (мінорністю), що, за словами Д. Павличка, властива ідіостилю П. Перебийноса: «панує печальне взаєморозуміння між усіма речами і всіма духовними екзистенціями. Філософія цього взаєморозуміння каже: все дійсне є сумним» (Павличко, 2011: 9). Таким може бути сум за закінченим літом і побоювання щодо прийдешнього осіннього холоду, виражені в опозиційному протистоянні “літо - осінь”: «Минуло літо. // (Холодно у світі). // Війнула осінь. // (Порожньо у сериі)». Якщо виділені сполуки позначають календарний часовий перехід, то сполуки з лексемами стану холодно та порожньо $€$ семантично негативними. Контент поезії становить спостереження за уявним метеликом, який виявився зрештою листочком: «в осінньофіолетовому небі блимав жовтий вогничок-метелик», що «зігрівав мої зіниці», «світився над осінньою душею», «самотньо кружеляв y високості» (Перебийніс, 1990: 108). Поряд з порівняно нейтральними за семантикою виділеними дієсловами, виділяємо тут колористичну ознаку неба - осінньо-фіолетове, що є одним з улюблених кольорів поета.

Мінорність, пов'язана із часовою площиною, більш конкретизується, суб'єктивуючись у площині віку ліричного героя, коли не лише традиційні елементи зими, снігу, грудня стають ознакою похилого віку автора, але й узагалі будь-які темпоральні, що відзначаються невідворотною плинністю. Наприклад, у фрагменті «Летять мої червневі дні, // в зінииях тануть сумовито, // немов нагадують мені, // як треба ними дорожити» (Перебийніс, 1990: 37) виділена дієслівна послідовність пов'язана із цим часовим процесом, а словосполучення треба ними дорожити конкретизує авторські почуття плинності часу (віку). Якщо в попередньому прикладі використано переважно периферійні елементи концепту «час», то у фрагменті «Вік минає, очі 
у завї» (Перебийніс, 1990: 82) виділяємо і приядерний елемент, а також метафору «очі у завї», конотовану мінорним ставленням до власного віку.

Тема нерозривного зв'язку ліричного героя (автора) із землею - одна з найголовніших у П. Перебийноса, що проходить через тематичні опозиції «космос - земля», «місто - село», «урбаністичне природне», маніфестуючи категорії «Батьківщина», «Поле / Степ». Наприклад, у межах опозиційної категорії «Місто», що передбачає переважно негативні ознаки - замкненість, мертвість, нещадність тощо, поет часом знаходить паростки живого, що пробивається до сонця. Зокрема, у поезії «Родючий асфальт» уже сама назва вказує на сутність подальшого контенту: асфальт постає як засіб умертвіння природи, він "розрівнює зелені байраки», "розтоптує червоні суниці», «засліплює наївні ромашки», «по насінню, корінню, пагінню прокочується вогнем і металом», тобто через виділені дієслова має семантику нещадності («і пройшлися нещцаднм котком») (Перебийніс, 1990: 94).

П. Перебийніс констатує власний творчий пріоритет на користь категорій «Село», «Поле / Степ» у поетичних рядках «Ніяк не можу примирити // иорнозем // з асфальтом» (Перебийніс, 1990: 47). Тобто він не вважає це протистояння антагоністичним і намагається поєднати опозиційні елементи, однак це не виходить (показник категоричності - сполука ніяк не можу). Зрештою, він зараховує до обох площин: «Я - засвічена частинка // всіх поєднаних світів» (Перебийніс, 1990: 132).

Ототожнення села й природи виявляється в порівнянні хати з білою качечкою в поезії «Біла качечка»: «Тітчина хата - // біла качечка над левадою - // пливла собі в день черешневии // і вікнооко позирала на город. // Скучала за тіткою» (Перебийніс, 1990: 60). Подвійність метафори полягає в тому, що зіставлення хати й качечки відбувається із залученням людських характеристик. Якщо дієслова пливла, дивилася та позирала можуть бути властиві качечці, то плакала й скучала властиві людині. Також ознаку хати як живого об’єкта репрезентовано прислівником вікнооко, що є похідною формою від авторського епітета (хата вікнооко позирала та плакала вікнооко). За формальною структурою вірша (з відокремленим означенням) пливла саме хата, схожа на качечку. Це уявлення відбувається через візуальний 
ефект - вибілені сільські хати сприймалися як невід’ємні від природи об’єкти, що на зеленому фоні виглядали як білі птахи.

Зазначене вище концептуальне ототожнення також виявляється у зв'язках тітки - господарки того будинку-качечки - та землі, в якій виростає городина. Цей зв’язок поет відбиває метафорично за допомогою дієслівних форм посаджені («руки були по плечі посаджені в землю. // Ми копали з тіткою картоплю») та приростає («тітка приростає до землі») (Перебийніс, 1990: 60). Це відповідає його особистому ставленню до рідних місць, які ототожнюються не лише з рідною природою, але й з матір'ю, і ці елементи він зіставляє в описі річки Мурашки - «вузенька, як перецвіла материнська коса» (Рубан, 1997: 52).

Не так частотністю, як виразністю в поета відзначається тема кохання. В. Базилевський слушно зазначає: «Інтим у Перебийноса піднесений і просвітлений. У ньому присутній культ жінки» (Базилевський, 2011: 566). Наприклад, для висловлення гострих особистих почуттів автор використовує антитезу природних ознак. У поезії «Єдиній» поет висловлює почуття кохання через протиставлення «грім у лютому» та «сніг у травні»: «I лютневим громом загриміло, // і травневим снігом защвіло. // Я погладив ніжно і несміло // молоде, сполохане крило» (Перебийніс, 1990: 82). Зіставлення дівчини з пташкою через орнітонімний іменник крило конкретизується означальним словосполученням чорнява ластівка. Такі гострі почуття, пов'язані з коханням, виявляються й у конструкціях, де до зіставлення плину життя з ознаками періодів року, що традиційно асоціюються $з$ людським віком, додаються й ознаки дівочості, що також зіставляються з бджолиними. Тобто відбувається багатошарове метафоричне зіставлення: «Завесніла, зазиміла, // карим вогником зійшла. // Карим сміхом задзвеніла, // мов на квіточці бджола» (Перебийніс, 1990: 84), де виділені дієслова позначають закінчені вікові проміжки, а епітет карий - ознаку жінки (ще далі - «карий сміх завереснів»).

Тема любові до України є однією з провідних у поета. Недарма він виголошує: «Одна любов у мене - Украӥна // моя земля-слов'янка y саду» (Перебийніс, 1990: 28), а також устами В. Сосюри: «Як же Украӥну не любити, // як без неї дихати мені?!» (Перебийніс, 1990: 12), хоча той у поезії «Сосюра пише “Третю Роту”» зазначає про рідний Донбас: «Тут моє коріння. // Терикони - кратери доби». П. Перебийніс 
недарма акцентує саме на регіональній приналежності родового коріння (терикони - як головна ознака шахтарського краю) - значення малої батьківщини в його творчості стоїть вище за все інше.

У тематичному колі окремою площиною визначається тема космосу, що репрезентована елементами однойменної концептуальної категорії - астронімів й астрономорфів. Зокрема, у поезії «Подільський зорешлях» (Перебийніс, 2011: 443) уже в назві зіставлено космічний простір із земним, а в подальшому тексті фіксуються космічні елементи: «За туманами густими // край планети багрянів». У поезії «Шлях на вершину» (Перебийніс, 1976: 75) астрономічні елементи зіставляються із зоологічними через «посередництво» ландшафтних елементів: «Немов розгнуздані булані, // переганяючи вітри, // стрибали хмари табунами // на груди гордої гори». Виділене словосполучення передає основне метафоричне зіставлення, що доповнюється іншими контекстуальними зоологізмами розгнуздані булані, переганяючи, астрономізмом вітри із залученням ландшафтної (просторової) метафори на груди гори.

Традиційним елементом категорії «космос» є лексема зірка, що взагалі найбільш частотна у світовій поезії всіх часів. У П. Перебийноса образ зірки уособлений через суб'єктивні чинники - зокрема через особисте звертання до неї ліричного героя за допомогою займенника 2-ї особи однини: «Де ти, зірко, згасла, озовися? // 3 безвісті хоч привидом сяйни // крізь небесні хащі прямовисні // усміхнись печально з далини» (Перебийніс, 1976: 74). Ознаками уособлення, крім виділених дієслів, $є$ також прислівник печально, що виконує функцію обставини способу дії. У подальшому фрагменті «Де ти, згасла зірко моя, де ти? // У сліпої ночі на краю, // на хисткому березі планети // я лицем до всесвіту стою» поет віртуально дорівнюється до зірки не лише духовно (через присвійний займенник моя), але й просторово (виділене словосполучення). Наявні тут і мінорні елементи, якими автор характеризує сучасний світ (згасла зірко моя, у сліпої ночі на краю, на хисткому березі планети).

Ядерні елементи всесвіт і космос у поета більшою мірою залучені в мінорному контексті: «А над Землею // всесвіт // буревіє // лихим вогнем космічних катастроф. // І розрива планету // аритмія // пророкуванням атомних голгоб» (Перебийніс, 1976: 73). Відзначаються негативною семантикою тут не лише виділені лексеми, але й ознаки 
найбільшої міри негативу у словосполученнях космічні катастрофи та атомні голгофи (за словником, катастрофа - «знищення, загибель, руйнація», голгоба - «місце страти, мук» (Великий тлумачний словник, 2001: 529, 249)), а також прихована негативна ознака «аритмія пророкуванням катастроф», де виділений іменник позначає загрозу від інформаційних спалахів песимістичних настроїв у тогочасному суспільстві.

\section{Висновки}

Можна зробити загальний висновок, що у творах поета переважають мінорні настрої, пов'язані із часовою площиною, зокрема віком ліричного героя, відзначені невідворотною плинністю часу. Ці настрої виявляються в темах захисту світу, природи, однак у темах відродження природи, вічності рідного села простежуються вже мажорні інтенції. Саме цей шлях - від негативу до позитиву, до мотивів відродження й розквіту - описується поетом у його творах. Ще один шлях - це політ душі в космічній далині з обов'язковим поверненням додому. До того ж у трансцендентальній площині зв'язок космосу із землею наповнюється ще й божественною силою.

Власне мовними ознаками ідіостилю П. Перебийноса $є$ фольклорність, представлена окремими традиційними формами (це, зокрема, звертання до об'єктів природи як живих співрозмовників), пісенність (через відповідні особливості віршування), майстерність створення метафоричних конструкцій, де поет зіставляє елементи космосу та землі, села й міста, рослинного, тваринного та водного світів, природних стихій та антропоморфних ознак. Загалом зазначені ознаки поетової мови входять до загального комплексу його творчої концептосфери.

\section{ЛІТЕРАТУРА}

1. Базилевський В. Де шукати універсальний зміст. Цивілізація дерев. Поезія. Драматургія. Київ: Український письменник, 2011. С. 564-577. 2. Великий тлумачний словник сучасної української мови. Київ; Ірпінь: ВТФ «Перун», 2001. 1440 с. 3. Жигун С. В. Гра як художній прийом в епічному тексті (на матеріалі української прози 10-20-х років XX ст.): автореф. дис. ... канд. філол. наук: 10.01.06. Київ, 2008. 18 с. 4. Ковалів Ю. І. Жанрово-стильові модифікації в українській літературі: моногр. Київ: ВПЦ «Київ. ун-т», 2012. 191 с. 5. Кощова А. В. Концептуальний аналіз: перспективи і переваги при вивченні художнього тексту. Уч. записки Таврического наи. унта им. В.И. Вернадского. Одесса, 2013. Т. 26 (65). № 1. С. 122-126. 6. Лисиченко Л. А. 
Лексико-семантичний вимір мовної картини світу. Харків: Вид. група «Основа», 2009. 191 с. 7. Лотман Ю. М. О поэтах и поэзии. Санкт-Петербург: Искусство СПб, 1996. 848 с. 8. Маслова В. А. Поэт и культура: Концептосфера М. Цветаевой. Москва: Флинта: Наука, 2004. 256 с. 9. Павличко Д. Погляд з вічності. Світ поезій Петра Перебийноса. Цивілізація дерев. Київ: Укр. письм., 2011. С. 5-11. 10. Перебийніс П. М. Пшеничний годинник. Київ: ВІК, 2005. 352 с. 11. Перебийніс П. М. Ранкові сурми: Поезії. Київ: Рад. письм., 1976. 104 с. 12. Перебийніс П. М. Точний час: Поезії. Київ: Рад. письм., 1990. 135 с. 13. Перебийніс П. М. Цивілізація дерев. Київ: Укр. письм., 2011. 392 с. 14. Поліщук Я. Фольклорний код в українській літературі. Дивослово. 2008. № 9. С. 45-49. 15. Рубан В. Він з покоління шістдесятників: Про поезію П. Перебийноса. Дивослово. 1997. № 5-6. С. 51-52. 16. Слабошпицький М. Віхи життя і творчості П. М. Перебийноса. Цивілізація дерев. Поезія. Драматургія. Київ: Укр. письм., 2011. С. 568-571. 17. Сорока П. І., Ониськів М. М. Світ поезії Петра Перебийноса. Тернопіль: Джура, 2005. 112 с. 18. Талалай Л. Срібна голка і нить золота: поезія А. Кичинського. Кур’єр Кривбасу. 2011. № 252-273. С. 376-383.

\section{REFERENCES}

1. Bazylevskyi, V. (2011). De shukaty universalnyi zmist. Tsyvilizatsiia derev. Poeziia. Dramaturhiia [Where to look for universal content. Tree civilization. Poetry. Drama]. Kyiv: Ukrainskyi pysmennyk [in Ukrainian]. 2. Busel, V. T. (2003). Velykyi tlumachnyi slovnyk suchasnoi ukrainskoi movy [A great explanatory dictionary of modern Ukrainian]. Kyiv: Perun [in Ukrainian]. 3. Zhyhun, S. V. (2008). Hra yak khudozhnii pryiom v epichnomu teksti (na materiali ukrainskoi prozy 10-20-kh rokiv XX st.) [Game as an artistic technique in an epic text]. Extended abstract of candidate's thesis. Kyiv: Kyiv. un-t im. B. Hrinchenka [in Ukrainian]. 4. Kovaliv, Yu. I. (2012). Zhanrovo-stylovi modyfikatsii $v$ ukrainskii literaturi [Genre-style modifications in Ukrainian literature]. Kyiv: Kyivskyi universytet [in Ukrainian]. 5. Koshchova, A. V. (2013). Kontseptualnyi analiz: perspektyvy i perevahy pry vyvchenni khudozhnoho tekstu [Conceptual analysis: prospects and advantages in the study of artistic text]. Uch. zapysky Tavrycheskoho nats. un-ta im. V. Y. Vernadskoho, 26 (65), 122-126 [in Ukrainian]. 6. Lysychenko, L. A. (2009). Leksyko-semantychnyi vymir movnoi kartyny svitu. [Lexical and semantic dimension of the linguistic picture of the world]. Kharkiv: Vyd. hrupa Osnova [in Ukrainian]. 7. Lotman, Yu. M. (1996). O poe'tax i poe'zii [About poets and poetry]. Sankt-Peterburg: Iskusstvo SPb [in Russian]. 8. Maslova, V. A. (2004). Poet y kultura: Kontseptosfera M. Tsvetaevoi [Poet and Culture: M. Tsvetaeva's Conceptosphere]. Moskva: Flinta: Nauka [in Russian]. 9. Pavlychko, D. (2011). Pohliad z vichnosti. Svit poezii Petra Perebyinosa. Tsyvilizatsiia derev [A view from eternity. The World of Poetry by Peter Perebynos. Tree civilization]. Kyiv: Ukrainskyi pysmennyk [in Ukrainian]. 10. Perebyinis, P. M. (2005). Pshenychnyi hodynnyk [Wheat clock]. Kyiv: VIK [in Ukrainian]. 11. Perebyinis, P. M. (1976). Rankovi surmy [Morning Antimony]. Kyiv: Radianskyi pysmennyk [in Ukrainian]. 12. Perebyinis, P. M. (1990). Tochnyi chas [Exact time]. Kyiv: Radianskyi pysmennyk [in Ukrainian]. 13. Perebyinis, P. M. (2011). Tsyvilizatsiia derev [Tree civilization]. Kyiv: Ukrainskyi pysmennyk [in Ukrainian]. 14. Polishchuk, Ya. (2008). Folklornyi kod v ukrainskii literaturi [Folklore Code in Ukrainian Literature]. Dyvoslovo, № 9, 45-49 [in Ukrainian]. 15. Ruban, V. (1997). Vin z pokolinnia shistdesiatnykiv: Pro poeziiu P. Perebyinosa [He is from the generation of the sixties: On the poetry of P. Perebynos]. 
Dyvoslovo, № 5-6, 51-52 [in Ukrainian]. 16. Slaboshpytskyi, M. (2011). Vikhy zhyttia $i$ tvorchosti P. M. Perebyinosa. Tsyvilizatsiia derev. Poeziia. Dramaturhiia [Milestones of life and creativity PM Interruptions. Tree civilization. Poetry. Drama.]. Kyiv: Ukrainskyi pysmennyk [in Ukrainian]. 17. Soroka, P. I. \& Onyskiv, M. M. (2005). Svit poezii Petra Perebyinosa [World of poetry of Peter Perebynos]. Ternopil: Dzhura [in Ukrainian]. 18. Talalai, L. (2011). Sribna holka i nyt zolota: poeziia A. Kychynskoho [Silver needle and thread of gold: poetry of A. Kichinsky]. Kherson: Kurier Kryvbasu [in Ukrainian].

Бєлінська Валерія Євгенівна - аспірант кафедри української мови, Харківський національний педагогічний університет імені Г. С. Сковороди. Вул. Валентинівська, 2, м. Харків, 61168, Україна.

Tel.: +38-095-517-58-03

E-mail: lerabelinskaya@i.ua

https://orcid.org/0000-0002-7276-0426

Bielinska Valeriia Yevhenivna - Postgraduate Student, Ukrainian Language Department, H. S. Skovoroda Kharkiv National Pedagogical University. Valentynivska Str., 2, Kharkiv, 61168, Ukraine.

Надійшла до редакції 09 жовтня 2019 року 